\title{
A coupled modelling effort to study the fate of contaminated sediments downstream of the Coles Hill deposit, Virginia, USA
}

\author{
CELSO F. CASTRO-BOLINAGA ${ }^{1}$, EDGARDO R. ZAVALETA ${ }^{1} \&$ \\ PANAYIOTIS DIPLAS ${ }^{2}$ \\ 1 Baker Environmental Hydraulics Laboratory, Department of Civil and Environmental Engineering, Virginia Tech, \\ Blacksburg, Virginia 24061, USA \\ ccastro@vt.edu \\ 2 Imbt Environmental Hydraulics Laboratory, Department of Civil and Environmental Engineering, Lehigh University, \\ Bethlehem, Pennsylvania 18015, USA
}

\begin{abstract}
This paper presents the preliminary results of a coupled modelling effort to study the fate of tailings (radioactive waste-by product) downstream of the Coles Hill uranium deposit located in Virginia, USA. The implementation of the overall modelling process includes a one-dimensional hydraulic model to qualitatively characterize the sediment transport process under severe flooding conditions downstream of the potential mining site, a two-dimensional ANSYS Fluent model to simulate the release of tailings from a containment cell located partially above the local ground surface into the nearby streams, and a onedimensional finite-volume sediment transport model to examine the propagation of a tailings sediment pulse in the river network located downstream. The findings of this investigation aim to assist in estimating the potential impacts that tailings would have if they were transported into rivers and reservoirs located downstream of the Coles Hill deposit that serve as municipal drinking water supplies.
\end{abstract}

Key words ANSYS Fluent; Coles Hill; HEC-RAS; mining; numerical modelling; sediment transport; tailings

\section{INTRODUCTION}

The Coles Hill deposit, located in south-central Virginia in the United States, is currently considered to be the largest known undeveloped uranium ore deposit in North America. It consists of an estimated resource of 120 million pounds $\left(54.4 \times 10^{6} \mathrm{~kg}\right)$ of uranium that represents, at the time of this study, enough fuel to supply all nuclear reactors in the United States for two years or the reactors in the State of Virginia for nearly forty years (Santoy Resources, 2009; US Energy Information Administration, 2010). If the site were to be developed, the mining and processing operations for extracting the uranium from the ore rock would generate considerable amounts of waste by-products, known as tailings (NRC, 2012). They contain approximately $85 \%$ of the rock original radioactivity and, according to regulations, must be stored on site, in containment cells designed to last over a thousand years without breaching (USNRC, 2002). Therefore, if ever released, tailings could pose a long-term hazard to human health and the surrounding environment.

The economic and environmental implications that the development of the Coles Hill site might have in the future have motivated the implementation of a large, comprehensive, and continuing investigation to characterize the geological, geochemical and hydrological conditions surrounding the deposit (Gannon et al., 2012; Kingston et al., 2012; Castro-Bolinaga \& Diplas, 2014; Levitan et al., 2014; Tappa et al., 2014). Part of this investigation included a coupled numerical modelling effort to study the fate of tailings due to a hypothetical containment cell failure triggered by an extreme hydrologic event. This paper focuses on the preliminary results of this modelling effort, which required the implementation of three separate component numerical models. The findings presented herein aim to assist in estimating the potential impacts that tailings would have if they were released and subsequently transported into rivers and reservoirs located downstream of the site that serve as municipal drinking water supplies.

Initially, the location of the Coles Hill deposit and the characteristics of the surrounding area are presented. Next, details of the separate component models are provided. These include a brief description of each component model, and information regarding the employed methodology, estimation of relevant parameters, calibration produced, and numerical simulations. Finally, the overall modelling effort results are presented and their implications are discussed. 


\section{STUDY AREA}

The Coles Hill deposit is located in central Pittsylvania County, east of the towns of Chatham and Gretna in the southern part of the State of Virginia. It is situated in a predominantly rural area characterized by dense forests and agricultural lands, where only a small percentage of developed regions exist in the surroundings. The two main uranium ore bodies that form the deposit are bounded by the channels of Mill Creek and Whitethorn Creek. The latter flows further downstream into the Banister River, which eventually flows into major regional water bodies such as the John H. Kerr Reservoir and Lake Gaston. The location of the Coles Hill deposit in relation to the nearby and downstream river network is illustrated in Fig. 1. The location of relevant landmarks (e.g. reservoirs) and hydraulic structures (e.g. dams) is included in Fig. 1 as well.

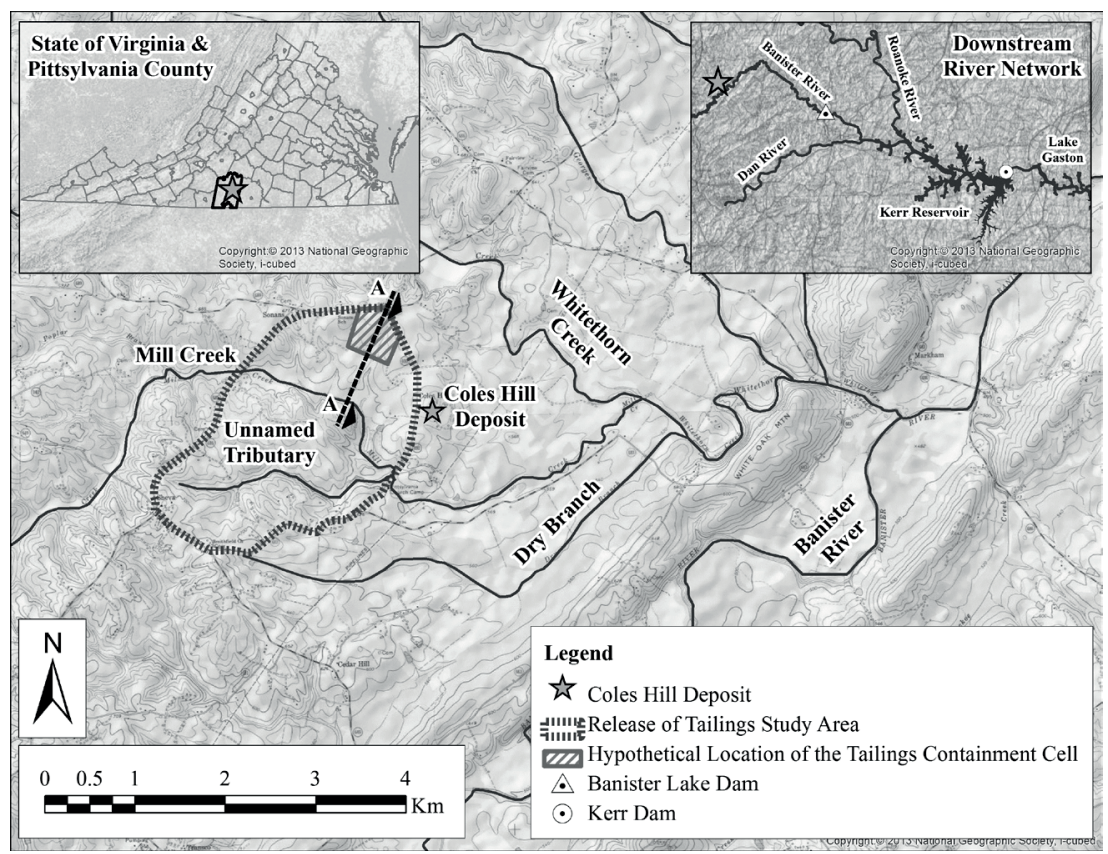

Fig. 1 Location of the Coles Hill deposit in relation to the nearby and downstream river network (data from USGS National Hydrography Dataset 2007; USGS Topographic Maps 2012).

\section{NUMERICAL MODELLING}

The coupled modelling effort employed in this study required the application of three separate component models. First, a one-dimensional (1D) hydraulic model to qualitatively characterize the sediment transport process under severe flooding conditions downstream of the Coles Hill deposit; second, a two-dimensional (2D) ANSYS Fluent model to simulate the release of tailings from a containment cell located partially above the local ground surface into the nearby streams; and third, a 1D sediment transport model to examine the propagation of a tailings sediment pulse in the river network located downstream of the site. The conceptual framework of the overall modelling process is presented in the flowchart shown in Fig. 2. A description for each of the component models illustrated in this flowchart is given within the next sections of this paper.

\section{Hydraulic component model}

The US Army Corps of Engineers (USACE) Hydrologic Engineering Center River Analysis System (HEC-RAS) model was used for representing and modelling the river reaches located downstream of the study site, and for characterizing the sediment transport under severe flooding conditions. HEC-RAS is a 1D mathematical model capable of performing hydraulic computations for a network of channels and flood plains (Brunner, 2010). This publically-available software package is widely used and accepted as industry standard for hydraulic modelling purposes. 


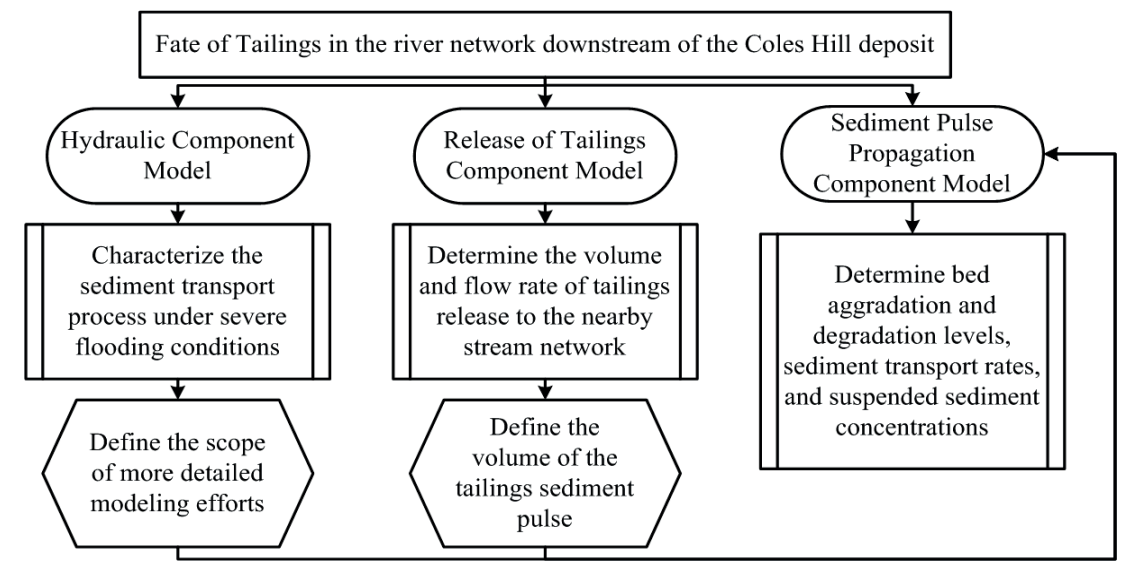

Fig. 2 Conceptual framework of the coupled modelling effort.

The hydraulic model included two river reaches: Whitethorn Creek from its confluence with Mill Creek to its confluence with the Banister River $(4.8 \mathrm{~km})$, and the Banister River from nearly one kilometre upstream of its confluence with Whitethorn Creek to approximately one kilometre downstream of the Banister Lake Dam $(53.8 \mathrm{~km})$ (Fig. 1). The selection of the latter reach was made to determine the degree of impact that this dam and its reservoir, the Banister Lake, have on the sediment transport process. The methodology employed for developing the hydraulic model included three main elements: (1) the construction of a river terrain model by combining publically-available datasets with field measurements, (2) a calibration procedure based on bankfull discharges obtained from developed site-specific stage-discharge predictor curves, and (3) unsteady flow simulations for the 10-, 50-, 100-, and 500-year storms, and the probable maximum flood (PMF) using the results from an event-based hydrologic model (Kingston et al., 2012). Due to space limitations, the reader is referred to Castro-Bolinaga \& Diplas (2014) for detailed information about each of these elements.

\section{Release of tailings component model}

The 2D computational fluid dynamics (CFD) ANSYS Fluent software (ANSYS, 2011) was used for simulating the worst-case scenario of the release of tailings from a containment cell into the nearby stream network. The specifics of this worst-case scenario were defined following regulations authored by the Nuclear Regulatory Commission (NRC) (USNRC, 1980) and the Code of Federal Regulation (USCFR, 2014). The ANSYS Fluent model utilized a hypothetical location of the containment cell that was selected based on the extent of the study area (Fig. 1) and the PMF inundation map (presented in Castro-Bolinaga \& Diplas, 2014). This location, which is shown in Fig. 1, permitted us to define a cross-sectional profile delineated by the characteristics of the surrounding terrain and hence establish a geometric configuration of the containment cell for modelling purposes (Fig. 3).

For the numerical simulations, only the volume of tailings that is located above the ground surface level was included $\left(0.43 \times 10^{6} \mathrm{~m}^{3}\right)$ (Fig. 3). The main properties of tailings, which are classified as silty-sand with $49 \%$ of fines, are presented in Table 1 . It was assumed for these simulations that tailings were in a liquefaction phase which was implemented in the ANSYS Fluent model by using the Bingham fluid formulation and the volume of fluid (VOF) solution technique (Jeyapalan et al., 1983; Huang et al., 2011). A total of 88000 quadrilateral meshing cells were used to discretize the modelling domain. The schematic representation of the tailings containment cell cross-sectional profile in the ANSYS Fluent model is depicted in Fig. 4. In this figure, the contours of volume fraction (VF) represents the ratio of the volume occupied by tailings to the total volume of each cell. In other words, a VF value equal to one implies that the cell is completely filled with tailings, whereas a VF value of 0.5 indicates that only half of the cell is full of tailings. 


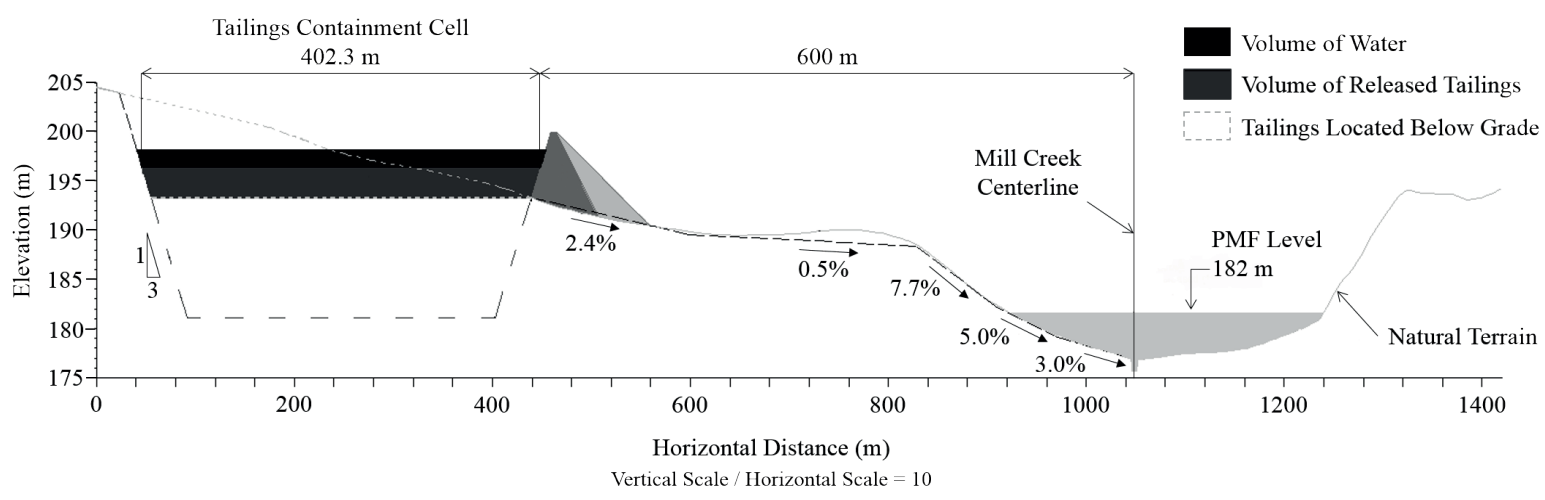

Fig. 3 Cross-section profile of the proposed tailings containment cell location within the study area in relation to Mill Creek (cross-section A-A in Fig. 1)

Table 1 Relevant properties of the tailings.

\begin{tabular}{lll}
\hline Property & Units & Value \\
\hline Dry (bulk) density & $\mathrm{kg} / \mathrm{m}^{3}$ & 1300 \\
Fully saturated density & $\mathrm{kg} / \mathrm{m}^{3}$ & 1800 \\
Plastic viscosity & $\mathrm{Pa} \cdot \mathrm{s}$ & 0.35 \\
\hline
\end{tabular}

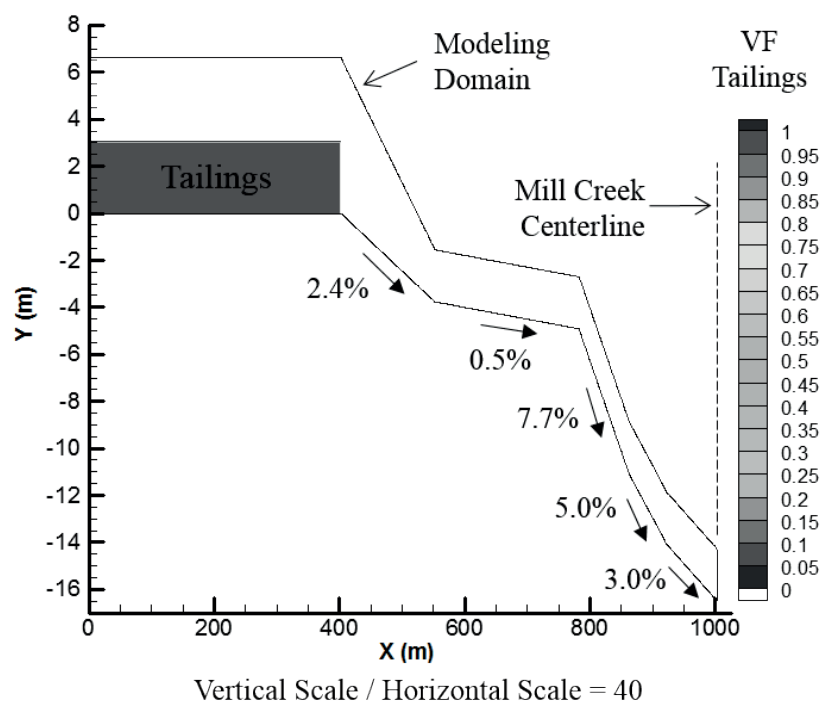

Fig. 4 Schematic representation of the tailings containment cell cross-sectional profile in the ANSYS Fluent model.

For validating the numerical model, the ANSYS Fluent model was used to simulate water dam break flows and the results were compared with data obtained from laboratory experiments conducted at the USACE Waterways Experimental Station (WES) (USACE, 1960). The comparison of both datasets indicated that the current model satisfactorily predicted the magnitude of the peak discharge, water depth, travel time, and propagation distance of the flood wave.

\section{Sediment pulse propagation component model}

A sediment pulse is defined as a large amount of loose sediment that is deposited into a river due to the action of external factors of natural or anthropogenic origin. Predominantly, these factors include landslides (Sutherland et al., 2002), tributaries (Lancaster et al., 2010), volcanic eruptions (Pierson et al., 2011), dam decommissioning (Wilcox et al., 2014), and mining-related activities (Pickup and Cui, 2009). In the case of the Coles Hill mining site, the failure of a containment cell 
would generate a tailings sediment pulse that would enter the nearby streams and significantly increase the sediment load to downstream reaches. Its occurrence would be associated with significant channel aggradation and degradation, possible damage of hydraulic structures (e.g. bridges), and potential impairment of aquatic habitats.

A 1D finite-volume model is currently being developed to examine the propagation of such tailings sediment pulse. The model consists of a hydraulic sub-model based on the St. Venant shallow water equations, a sediment transport sub-model that considers the movement of material as bedload and suspended load, and a morphological evolution sub-model to account for the mobility of the channel bed due to the exchange of sediment with the water column. Two methodologies, a decoupled and a coupled, will be used to solve the system of governing equations. The decoupled approach assumes that the morphological evolution of the sediment pulse at each time step is rather small and does not affect the surrounding flow field (referred to as the quasi-steady assumption). Therefore, the flow and sediment transport equations are solved separately. On the other hand, the coupled approach disregards the quasi-steady assumption and solves the governing equations simultaneously $(\mathrm{Wu}, 2008)$.

The application of either of the aforementioned approaches will be dictated by the rate and scale at which the dynamic interactions among the flow, transport of sediment, and morphological evolution (or mobility) of the channel bed occur. The decoupled approach is employed in cases where sediment is mainly transported as bedload, sediment concentrations in the water column are low, and the morphological evolution of the bed is slow (e.g. propagation of coarse-grained sediment pulses in gravel-bed rivers). The coupled approach is utilized to simulate fluvial processes in which the dominant mode of sediment transport is suspended load, sediment concentrations in the water column are high, and the morphological evolution of the bed is rapid (e.g. dam-break and hyperconcentrated flows).

\section{RESULTS AND DISCUSSION}

\section{Sediment transport characterization}

Results from the hydraulic component model for the 10-, 50-, 100-, and 500-year storm, and the PMF were used to develop longitudinal profiles of flow velocity and shear stress. These two variables were selected because they provide a direct measure of the capacity of the modelled rivers to carry sediment. The profiles corresponding to the reach of the Banister River that contains Banister Lake (Fig. 5) graphically illustrate the degree of impact that this reservoir have on the evaluated variables. It can be observed from Fig. 5 that the flow velocity and shear stress are significantly reduced for all the considered hydrologic events as water enters Banister Lake. Results indicate that the maximum reduction of the flow velocity is attained for the 10 -year storm with a value of $57.1 \%$, while the minimum reduction is found for the 500 -year storm and is equal to
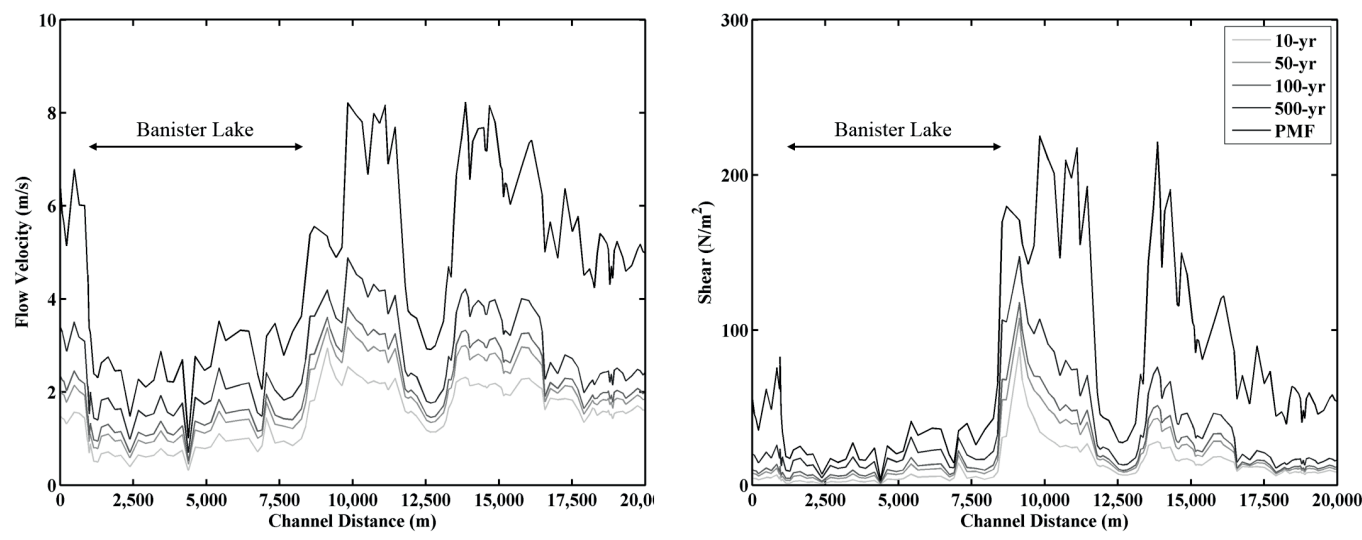

Fig. 5 Longitudinal profiles of flow velocity (left) and shear stress (right) for the reach of the Banister River containing the Banister Lake. 
$42.6 \%$. Similarly, the maximum and minimum reduction of the shear stress are related to the 10 year storm $(72.6 \%)$ and the 500-year storm $(54.5 \%)$, respectively (Castro-Bolinaga \& Diplas, 2014).

The findings presented herein show that the capacity of the Banister River to move sediment in the downstream direction is considerably reduced by the presence of the Banister Lake. The effectiveness of this water body in trapping material, however, will also depend on the grain size distribution, particle shape, and percentage of material in the clay and silt range of the inflowing sediment (USACE, 1995). Furthermore, the results of the sediment transport characterization provide preliminary and valuable insights for examining the propagation of the tailings sediment pulse in the river network downstream of the Coles Hill deposit. They permit definition of the scope and facilitate the development of this modelling effort by illustrating the particularities of the sediment transport process associated with the modelled river reaches.

\section{Release of tailings to the nearby stream network}

Results from the ANSYS Fluent model indicate that the downslope movement of tailings would occur very rapidly. As observed in Fig. 6, after only 50 seconds a considerable amount of material has already propagated towards the nearby stream network. For the considered hypothetical location of the containment cell (Fig. 1), the model predicted that tailings would initially reach the watercourse after approximately $1.5 \mathrm{~min}$, with $95 \%$ of the total simulated volume $\left(0.43 \times 10^{6} \mathrm{~m}^{3}\right)$ being released in nearly 25 min (Fig. 6).
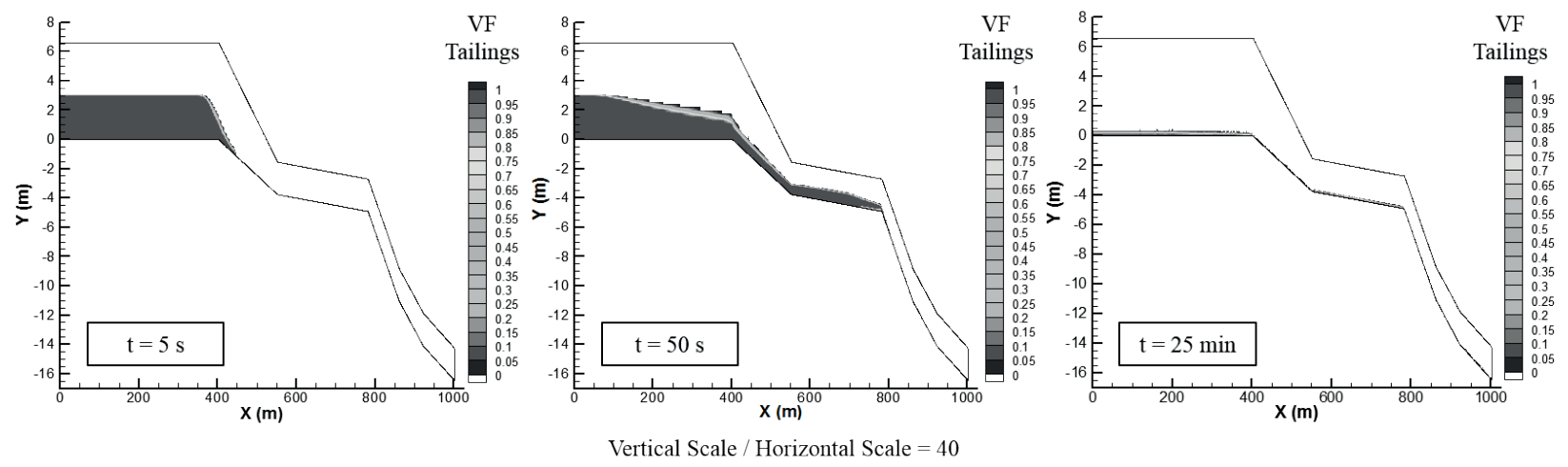

Fig. 6 Rate of evolution of the downslope movement of tailings from the containment cell into the nearby stream network.

Furthermore, the amount of tailings released from the containment cell can be represented as a sediment graph (Fig. 7). This diagram shows the variation of the volumetric flow rate and the total volume of tailings released with time. As depicted in Fig. 7, the main volume of released tailings would reach the nearby stream network approximately $5 \mathrm{~min}$ after the containment cell failure, with a volumetric peak flow rate equal to $2136 \mathrm{~m}^{3} / \mathrm{s}$.

Results from the ANSYS Fluent model indicated that the volume and speed of the released tailings are highly dependent on their plastic viscosity and grain size distribution, as well as on the slope of the terrain downstream from the containment cell location to the nearby stream network. The findings of the release of tailings component model presented herein, in particular the volumetric flow rate and the volume of released tailings, represent key inputs for implementation of the subsequent sediment pulse propagation model.

\section{Propagation of the tailings sediment pulse}

The introduction of a considerably finer tailings sediment pulse in the coarser sand-bedded reaches of Whitethorn Creek and the Banister River (Fig. 8) will be associated with elevated transport rates and significant amounts of material being transported as suspended load. This situation will result 


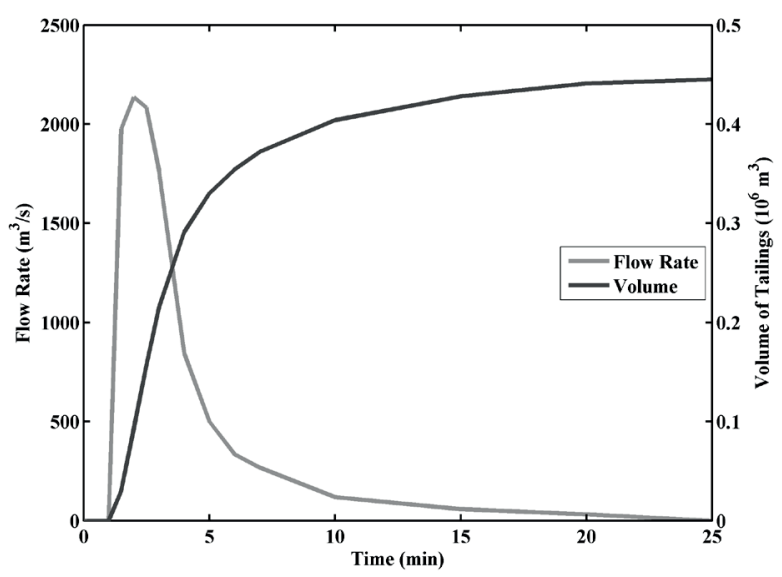

Fig. 7 Sediment graph and volume of tailings released to the nearby stream network.

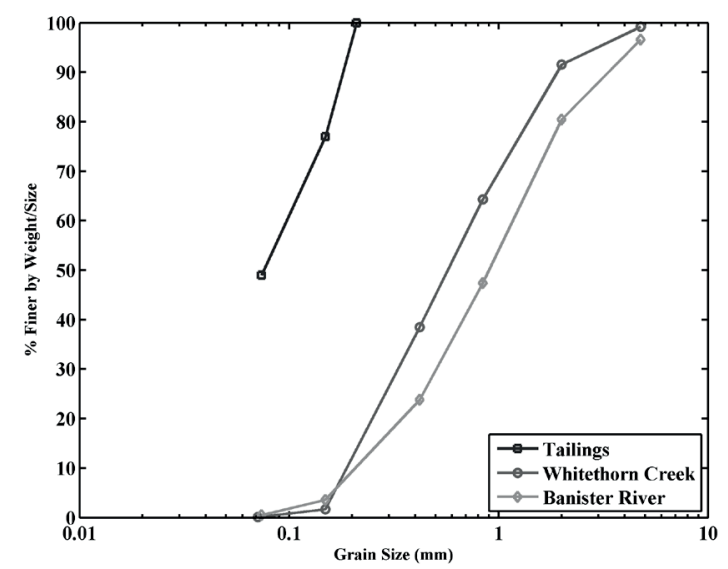

Fig. 8 Grain size distribution of tailings and two representative river bed material sediment samples of Whitethorn Creek and the Banister River.

in flows having strong eroding capabilities that generate very active transport processes and rapid bed evolution (Cao et al., 2004, 2006). Additionally, these flows will have the potential to trigger transient hyperconcentrated flows during the sediment pulse propagation process (e.g. Wilcox et al., 2014).

The 1D finite-volume model that is currently under development will focus on examining the propagation of fine-grained sediment pulses in sand-bed streams and the geomorphic response of river corridors to their occurrence. As defined by the sediment transport characterization results, the model will include the river reaches located between the Coles Hill deposit and the Banister Lake Dam. It is expected that results from this model will contribute towards the understanding of how the magnitude, duration and frequency of flows, the spatial complexity of natural river channels, and the occurrence of phenomena such hyperconcentrated flows affect the evolution of sediment pulses.

\section{CONCLUDING REMARKS}

A coupled modelling effort was implemented to study the fate of tailings downstream of the Coles Hill deposit. The overall modelling process included a 1D hydraulic model to characterize the sediment transport process, a 2D ANSYS Fluent model to simulate the release of tailings from a containment cell into the nearby stream network, and a 1D numerical model to examine the propagation of a tailings sediment pulse downstream of the potential mining site. The following concluding remarks were developed based on the results presented herein: 
- The Banister Lake, located approximately $54 \mathrm{~km}$ downstream of the Coles Hill deposit, acts a control point in the modelled river network. The presence of this water body causes a significant reduction of the flow velocity and shear stress and hence enhances the deposition of sediment as flowing water reaches the lake.

- Tailings released from the considered hypothetical location of the containment cell will reach the watercourse within approximately $1.5 \mathrm{~min}$. The $95 \%$ of the total simulated volume being released will be delivered to the watercourse in about $25 \mathrm{~min}$.

- The developed sediment graph indicates that the main volume of released tailings would reach the nearby stream network approximately $5 \mathrm{~min}$ after the containment cell failure, with a volumetric peak flow rate equal to $2136 \mathrm{~m}^{3} / \mathrm{s}$.

Acknowledgements The authors thank Virginia Uranium, Inc. (VUI) for the support provided during the course of this investigation. Additionally, the authors acknowledge Walter Coles, Sr., Joseph Aylor, Robert Bodnar, Alan Kuhn, and the rest of the members of the VT-VUI research group for their valuable comments and suggestions that improve the presentation of this work.

\section{REFERENCES}

ANSYS (2011) ANSYS Fluent User's Guide. ANSYS, Inc.

Brunner, G. W. (2010) HEC-RAS River Analysis System User's Manual, Version 4.1. US Army Corps of Engineers Hydrologic Engineering Center.

Cao, Z., et al. (2004) Computational dam-break hydraulics over erodible sediment Bed. J. Hydraul. Eng. 130(7), 689-703, doi: 10.1061/(ASCE)0733-9429(2004)130:7(689).

Cao, Z., Pender, G. \& Carling, P. (2006) Shallow water hydrodynamic models for hyperconcentrated sediment-laden floods over erodible bed. Adv. Water Resour. 29, 546-557, doi: 10.1016/j.advwatres.2005.06.011.

Castro-Bolinaga, C.F. \& Diplas, P. (2014) Hydraulic modeling of extreme hydrologic events: case study in southern Virginia. $J$. Hydraul. Eng. 05014007, 12, doi: 10.1061/(ASCE)HY.1943-7900.0000927.

Gannon, J.P., Burbey, T.J., Bodnar, R.J. \& Aylor, J. (2012) Geophysical and geochemical characterization of the groundwater system and the role of the Chatham Fault in groundwater movement at the Coles Hill uranium deposit, Virginia, USA. Hydrogeology Journal 20, 45-60, doi: 10.1007/s10040-011-0798-y.

Huang, Y., et al. (2012) Computational fluid dynamics modeling of post-liquefaction soil flow using the volume of fluid method. Bull. Eng. Geol. Environ. 71, 359-366, doi: 10.1007/s10064-011-0386-3.

Jeyapalan, J.K., Duncan, J.M. \& Seed, H.B. (1983) Analyses of flow failures of mine tailings dams. J. Geotech. Engrg. 109(2), 150-171, doi: 10.1061/(ASCE)0733-9410(1983)109:2(150).

Kingston, W.J., et al. (2012) Probable maximum flood inundation modeling: a case study in southern Virginia. In: Proc. River Flow 2012 (ed. by R. Murillo), 969-976. Taylor and Francis Group.

Lancaster, S.T., Underwood, E.F. \& Frueh, W.T. (2010) Sediment reservoirs at mountain stream confluences: Dynamics and effects of tributaries dominated by debris-flow and fluvial processes. GSA Bulletin 122(11/12), 1775-1786, doi: 10.1130/B30175.1.

Levitan, D.M., et al. (2014) Developing protocols for geochemical baseline studies: An example from the Coles Hill uranium deposit, Virginia, USA. Applied Geochemistry 43, 88-100, doi: 10.1016/j.apgeochem.2014.02.007.

National Research Council (NRC) (2012) Uranium Mining in Virginia: Scientific, Technical, Environmental, Human Health and Safety, and Regulatory Aspects of Uranium Mining and Processing in Virginia. The National Academies Press.

Pickup, G. \& Cui, Y. (2009) Modeling the impact of tailings and waste rock disposal on the Fly River System. In: The Fly River, Papua New Guinea: Environmental Studies in an Impacted Tropical River System (ed. by B. Bolton), 257-289. Elsevier.

Pierson, T.C., Pringle, P.T. \& Cameron, K.A. (2011) Magnitude and timing of downstream channel aggradation and degradation in response to a dome-building eruption at Mount Hood, Oregon. GSA Bulletin 123(1/2), 3-20, doi: 10.1130/B30127.1.

Santoy Resources LTD (2009) Technical Report on the Coles Hill Uranium Property Pittsylvania County, Virginia, USA, NI 43-101. Santoy Resources.

Sutherland, D.G., et al. (2002) Evolution of a landslide-induced sediment wave in the Navarro River, California. GSA Bulletin 114(8), 1036-1048, doi: 10.1130/0016-7606(2002)114<1036:EOALIS >2.0.CO;2.

Tappa, M.J., et al. (2014) Age of host rocks at the Coles Hill uranium deposit, Pittsylvania County, Virginia, based on zircon U$\mathrm{Pb}$ Geochronology. Economic Geology 109(2), 513-530, doi: 10.2113/econgeo.109.2.513.

USACE (1960) Floods Resulting from Suddenly Breached Dams, Report 1, Conditions of Minimum Resistance, Hydraulic Model Investigation. Miscellaneous Paper No. 2-374. US Army Corps of Engineers.

USACE (1995) Sedimentation Investigations of Rivers and Reservoirs. USACE Engineering and Design Manual Publication No. EM 1110-2-4000. US Army Corps of Engineers.

USCFR (2014) Criteria relating to the operation of uranium mills and the disposition of tailings or wastes produced by the extraction or concentration of source material from ores processed primarily for their source material content, Title 10 , Part 40, Appendix A. U.S. Code of Federal Regulations.

US Energy Information Administration (2010) Uranium Purchased by Owners and Operators of U.S. Civilian Nuclear Power Reactors. Available from: http://www.eia.gov/cneaf/nuclear/umar/ summarytable1.html (Oct. 23, 2012).

USGS National Hydrography Dataset (NHD) (2007). Available from: http://nhd.usgs.gov/ (Jun. 23, 2014). 
USNRC (1980) Final Generic Environmental Impact Statement on Uranium Milling, Project M-25, Summary and Text, Volume I, NUREG-0706. U.S. Nuclear Regulatory Commission.

USNRC (2002) Design of Erosion Protection for Long-Term Stabilization: Final Report, NUREG-1623. U.S. Nuclear Regulatory Commission.

USGS Topographic Maps (2012). Available from: http://nationalmap.gov/ustopo/ (Jun. 23, 2014).

Wilcox, A.C., O'Connor, J.E. \& Major, J.J. (2014) Rapid reservoir erosion, hyperconcentrated flow, and downstream deposition triggered by breaching of $38 \mathrm{~m}$ tall Condit dam, White Salmon River, Washington. J. Geophys. Res. Earth Surf. 119, doi: 10.1002/2013JF003073.

Wu, W. (2008) Computational River Dynamics. Taylor \& Francis Group. 